\title{
New Perspectives for the Use of Earthworms - Testing of Anesthetics
}

\author{
Agnieszka Podolak1, Joanna Kostecka', Anna Rożen², Mariola Garczyńska', \\ Grzegorz Pączka', Anna Mazur-Pączka', Renata Szura'
}

1 Department of Natural Theories of Agriculture and Environmental Education, Faculty of Biology and Agriculture, University of Rzeszow, Cwiklinskiej 1A, 35-601 Rzeszow, Poland

2 Department of Ecosystem Studies, Institute of Environmental Sciences, Jagiellonian University, Gronostajowa 7, 30-387 Krakow, Poland

* Corresponding author's e-mail: apodolak@poczta.fm

\begin{abstract}
Anesthetic drugs have been tested for years on rats, rabbits, dogs, cats and monkeys, which may raise ethical concerns. Researchers do not always pay attention to the possibility of using techniques of anesthesia, analgesia or euthanasia in relation to invertebrate animals. It has previously been shown that earthworms meet the requirements of laboratory animals, and being a good alternative to the studies on vertebrates, may also be used as the first stage of testing anesthetics. The lethal concentrations of procaine and lidocaine for E. fetida and D. veneta were established using modified filter paper contact test. Using a modified method developed for testing anesthetics, mature earthworms (clitellate) of both species were used to check the effectiveness of lidocaine and procaine in safe immobilizing of earthworms. The reactions of earthworms in contact with anesthetics were different. The possibility of using a higher concentration range of procaine and lidocaine for E. fetida than for D. veneta, as E. fetida demonstrated a greater resistance to the stress caused by the action of chemical substances. The response to this stress varied and depended on the concentration used; however, higher concentrations of anesthetics caused rapid body movements and discharge of the coelomic fluid as well as morphological changes observed after 48 hours. Procaine was not effective in immobilizing earthworms, but lidocaine proved effective in reversibly immobilizing both species. For E. fetida, lidocaine in the concentrations of 1.4 and 1.6 at 95 and 90 min, respectively, resulted in a full immobilization of animals, which then survived following $24 \mathrm{~h}$ and $48 \mathrm{~h}$ of recovery. For $D$. veneta, lidocaine in the concentrations 1.3 and 1.4 during 40 min proved effective and safe to use, as all individuals survived following $24 \mathrm{~h}$ and $48 \mathrm{~h}$ of recovery.
\end{abstract}

Keywords: Eisenia fetida (Savigny 1826), Dendrobaena veneta (Rosa 1893), bioassays, testing anesthetics, animal's welfare

\section{INTRODUCTION}

Anesthesia is a treatment aimed at suppressing the sensitivity to stimuli, inhibiting the sensation of pain and movements of the anesthetized body fragment without losing consciousness [Sadowski, 2012]. Physical (e.g. freezing the selected body area with ethyl chloride - inhibiting sensory nerve conduction) or chemical (using appropriate chemical substances - anesthetics) [Danysz and Buczko, 2008] methods are used to obtain effective anesthesia. Local anesthetics are the drugs that cause transient and reversible anesthesia without damaging nerve fibers. Their action is based on the reversible inhibition of the conductivity in nerve fibers. It is limited to the area in which they are applied; therefore, in most cases, they do not cause the central nervous system to be inhibited. The mechanism of their action consists in blocking the voltagedependent sodium channels which cause the nerve impulses to be conducted, resulting in a loss of sensation (at higher concentrations also the prevention of movement). In other words, local anesthetics block the action potentials that allow nerve conduction. The lipophilic (unprotected) form of anesthetics penetrates through the membrane into 
the cell, protonating the cationic form, thus blocking the sodium channel from the inside [Feinstein et al., 1977, Butterworth et al., 1987, Bouazizi et al., 1998, Langwiński, 2008; Bujak-Giżycka et al., 2009]. Anesthetics, in chemical terms, are weak bases consisting of lipophilic and hydrophilic parts. They are provided with an ester or amide bond. The type of bonding determines the group to which the individual substances belong. The amine esters are distinguished by procaine, cocaine, teteracaine, and benzocaine. Aminoamides include, for example, lidocaine, prilocaine, mepivacaine, bupivacaine, levobupivacaine, etiocaine and ropivacaine. The type of bonding involved influences the metabolism of the drug inside the body. Aminoesters provided with an ester link are characterized by a short half-life (minutes) and are therefore rapidly broken down by plasma and tissue esterases. However, anesthetics having an amide bond are broken down only in the liver as a result of the action of amidases, therefore their half-life is much longer [Langwiński, 2008, Bujak-Giżycka, 2009]. Anesthetic drugs have been tested for years on rats, rabbits, dogs, cats and monkeys, which may raise ethical concerns [Mepham, 2008]. Researchers do not always pay attention to the possibility of using techniques of anesthesia, analgesia or euthanasia in relation to invertebrate animals. However, according to the literature, various techniques are being tested for the anesthesia of invertebrates. Inhalation anesthesia is used in terrestrial invertebrates using a special gas chamber. In relation to land and water mollusks, water-soluble anesthetics are used [Cooper, 2011]. It has previously been shown that earthworms meet the requirements of laboratory animals, and being a good alternative to studies on vertebrates, may also be used as the first stage of testing anesthetics [Podolak-Machowska et al., 2012, 2013]. At the same time, the results of these studies seem promising in terms of providing better animal welfare during research.

The aim of the research was to determine $\mathrm{LC}_{05}, \mathrm{LC}_{50}$ and $\mathrm{LC}_{95}$ for procaine and lidocaine and test them for effectiveness in safe immobilisation of the E. fetida and $D$. veneta earthworms.

\section{MATERIALS AND METHODS}

\section{Animals}

Mature earthworms (clitellate) of Eisenia fetida (Savigny, 1826) and Dendrobaena veneta
(Rosa, 1893) (Annelida, Oligochaeta) were used for the experiments. The animals were in good health and were characterized by average mobility. In order to clean their digestive systems and confirm good health condition, the earthworms were kept for 24 hours on wet tissue paper prior to the exposure to experimental treatments. The earthworm cultures were maintained under controlled laboratory conditions (air conditioning chamber $-18 \pm 2^{\circ} \mathrm{C}, 24 \mathrm{~L}$ ) in plastic boxes filled with soil (culture medium) and protected against moisture loss. The earthworms were regularly fed ad libidum (pomace from apples, carrot and beetroot, cooked potatoes + cellulose in a ratio of 4: 1).

\section{Tested substances}

Local anesthetic drugs - procaine hydrochloride $\left(\mathrm{C}_{13} \mathrm{H}_{20} \mathrm{~N}_{2} \mathrm{O}_{2} \times \mathrm{HCl}\right) \quad \mathrm{m}=$ $272.77 \mathrm{~g} / \mathrm{mol}$ and lidocaine hydrochloride monohydrate $\left(\mathrm{C}_{14} \mathrm{H}_{22} \mathrm{~N}_{2} \mathrm{O} \times \mathrm{HCl} \times \mathrm{H}_{2} \mathrm{O}\right) \mathrm{m}=288.81 \mathrm{~g} / \mathrm{mol}$ (SIGMA-ALDRICH) were used. Appropriate concentrations of solutions of the substances were prepared, in which PBS was the solvent. On the basis of the earthworm mortality, a range of concentrations (close to $\mathrm{LC}_{50}$ pilot tests) were used in the toxicity tests for each substance and species.

\section{Establishing of $\mathrm{LC}_{05^{\prime}} \mathrm{LC}_{50}$ and $\mathrm{LC} \mathrm{C}_{95}$}

The lethal concentrations of procaine and lidocaine for E. fetida and D. veneta were established using a modified filter paper contact test [OECD, 1984]. For E. fetida, 21 successive concentrations of procaine and lidocaine were used (every $0.2 \%$ from 0.2 to $4.2 \%$ - the average body weight of individuals: $0.36 \pm 0.058 \mathrm{~g}$ ). For $D$. veneta, 22 consecutive concentrations were used (every $0.1 \%$ from 0.1 to $2.2 \%$ - the average body weight of individuals: $1.11 \pm 0.289 \mathrm{~g}$ ). $1 \mathrm{ml}$ of the tested solution was added to petri dishes (diameter 8 $\mathrm{cm}$ ) lined with pellets of filter paper (Watmann No. 1 , diameter $8 \mathrm{~cm}$, thickness $0.2 \mathrm{~mm}$ ), into which worms were placed individually. The toxicity tests were carried out for $24 \mathrm{~h}\left(18 \pm 2^{\circ} \mathrm{C}\right.$, $24 \mathrm{D})$, after which earthworms were individually transferred to test tubes (Falcon - $50 \mathrm{ml}$ ) with wet tissue (no anesthetic). The earthworms were kept here for another 24 hours (to confirm or rule out mortality). After $24 \mathrm{~h}$, the morphological changes in earthworm bodies were checked, as well as their mobility (reaction to touch by forceps). 
On the basis of these observations, the percentage of animal mortality in each of the analyzed concentrations was determined. Five replicates of the experimental system were used, each in combination with the control group $-0 \%$ (a total of 220 E. fetida and 230 D. veneta tested). The experiments were carried out in a similar manner for the two substances tested. The obtained results allowed determination of the concentrations at which mortality was observed in $5 \%$ of the population $\left(\mathrm{LC}_{05}\right), 50 \%$ of the population $\left(\mathrm{LC}_{50}\right)$ and $95 \%$ of the population $\left(\mathrm{LC}_{95}\right)$. The $\mathrm{LC}$ values were calculated taking into account the mortality rate of individuals as a result of contact with consecutive concentrations of anesthetics using the statistical software Probit in SPSS 20.0 (IBM SPSS, 2011) [OECD, 1984, Łebkowska et al., 2004, Zuharah et al., 2014].

\section{The effectiveness of lidocaine and procaine in safe immobilizing of earthworms}

Using a modified method developed for testing anesthetics [Podolak-Machowska et al., 2013, 2014], mature earthworms (clitellate) of the species $E$. fetida (mean body weight $-0.43 \pm 0.130 \mathrm{~g}$ ) and $D$. veneta (mean body weight $-0.92 \pm 0.201 \mathrm{~g}$ ) were used. The animals were placed in beakers (diameter $5.5 \mathrm{~cm}$ ) containing $20 \mathrm{ml}$ of the appropriate anesthetic solution (10 animals per beaker). Next, the reaction of earthworms to stress was observed following contact with the chemical solution (motility, expulsion of the coelomic fluid, morphological changes), following successive stages of exposure to anesthetics. At the time when all individuals in the group did not show spontaneous or induced mobility (touch), the observations were terminated. The earthworms were rinsed in water to wash away the anesthetic substance, and then transferred to wet paper (in closed boxes) and left to recover. After $24 \mathrm{~h}$, survival was checked, any morphological changes were observed and the mobility of earthworms from the experimental and control groups was compared. The research was conducted separately for procaine and lidocaine for both species of earthworm, at a temperature of $18 \pm 2{ }^{\circ} \mathrm{C}$. Five replicates of the experimental system were used.

\section{Statistical analyses}

STATISTICA v. 10 (StatSoft) was used for statistical analyses. The recorded parameter values for $\mathrm{LC}_{05}, \mathrm{LC}_{50}$ and $\mathrm{LC}_{95}$ were expressed as mean values and standard deviations and ANOVA II. $\alpha=0.05$ was established as the level of significance. Before using the appropriate tests, it was checked that the distribution was consistent with a normal distribution ( $W$ Shapiro-Wilk test) and if the variances in groups were homogeneous (Brown-Forsyth test).

\section{RESULTS AND DISCUSSION}

\section{Reaction of $E$. fetida and $D$. veneta earthworms to different concentrations of procaine and lidocaine in filter paper contact tests}

The contact of E. fetida earthworms with higher concentrations of procaine and lidocaine $(2.0-4.2 \%)$, caused an immediate reaction in the form of violent writhing of animals and the extrusion of coelomic fluid. In the control group and at lower concentrations $(0-1.8 \%)$ no similar earthworm reaction was observed. The $D$. veneta earthworms exposed to chemical stress were more sensitive than the E. fetida earthworms, as evidenced by the much lower range of concentrations established on the basis of pilot tests preceding the proper tests. All specimens of this species placed in dishes containing appropriate concentrations of the tested anesthetics (0.2$2.2 \%$ ) showed an immediate reaction in the form of sudden body movements, resulting in the extrusion of the coelomic fluid. After 60 minutes of contact between earthworms of both species and anesthetics, it was observed that as the concentration of anesthetic substances increased, the earthworms demonstrated lower mobility, compared to control groups. With increase in the concentration of procaine and lidocaine (E. fetida $1.0-4.2 \%, D$. veneta $0.2-2.2 \%$ ), the appearance of subsequent morphological changes was also observed.

After $48 \mathrm{~h}(24 \mathrm{~h}$ exposure per substance $+24 \mathrm{~h}$ recovery), it was found that with increasing concentrations of anesthetics, the mortality of earthworms increased. For the species E. fetida at the $4.2 \%$ concentration of procaine and lidocaine, the mortality rate was $100 \%$. For $D$. veneta, mortality was $100 \%$ with a procaine concentration of $2.2 \%$. Lidocaine induced a faster death rate of $D$. veneta earthworms, since at the $0.6 \%$ concentration the majority of the animals tested were lost and $0.8 \%$ was a lethal concentration for all earthworms 
tested by D. veneta (Figure 1). At the same time, the earthworm mortality in the control group and in the lower concentrations remained at $0 \%$.

After $24 \mathrm{~h}$ of dermal contact (plus $24 \mathrm{~h}$ of recovery), with the tested anesthetics, E. fetida and $D$. veneta similar reactions of earthworms to both substances were observed, depending on the concentration of the agents used:

- individuals in the control groups $(0 \%)$ moved under the moist paper and remained curled up in a ,knot"; most of the animals from the experimental groups remained on the surface of the paper, despite initially attempting to escape via the walls of the dishes;

- as a result of the influence of chemical treatments, the presence of numerous morphological changes in the form of petechiae, discoloration and narrowing of the body was observed; in some individuals autotomy of the end segments was noted;

- earthworms from the groups exposed to higher concentrations were in the initial phase of decomposition after $24 \mathrm{~h}$, and with increasing concentrations of anesthetics the intensity of the morphological changes was greater.
The conducted toxicity tests allowed the determination and comparison of the concentrations of procaine and lidocaine which caused the mortality of $5 \%, 50 \%$ and $95 \%$ of the subjects of the studied population $\left(\mathrm{LC}_{05}, \mathrm{LC}_{50}\right.$ and $\left.\mathrm{LC}_{95}\right)$. This may be important information for using earthworms as biotests (Table 1).

Comparing the values of the calculated $\mathrm{LC}_{05}$, $\mathrm{LC}_{50}$ and $\mathrm{LC}_{95}$ concentrations for $E$. fetida, no differences were found for the two tested substances (Table 1). This was not the case for $D$. veneta, for which the calculated mortality induced by a specific number of subjects was significantly lower for lidocaine compared to procaine (Table 1). The lower range of concentrations used in the experiment for D. veneta (based on previous pilot tests) and therefore lower LC values indicate that the $D$. veneta earthworms were also, in this case, more sensitive to the substances used than E. fetida. The results of the tests showed that procaine was not effective at immobilizing earthworms, while lidocaine can be successfully used for the reversible immobilization of both $E$. fetida and D. veneta. In previous studies, prilocaine was a good anesthetic for D. veneta [Podolak-Machowska et al., 2014].
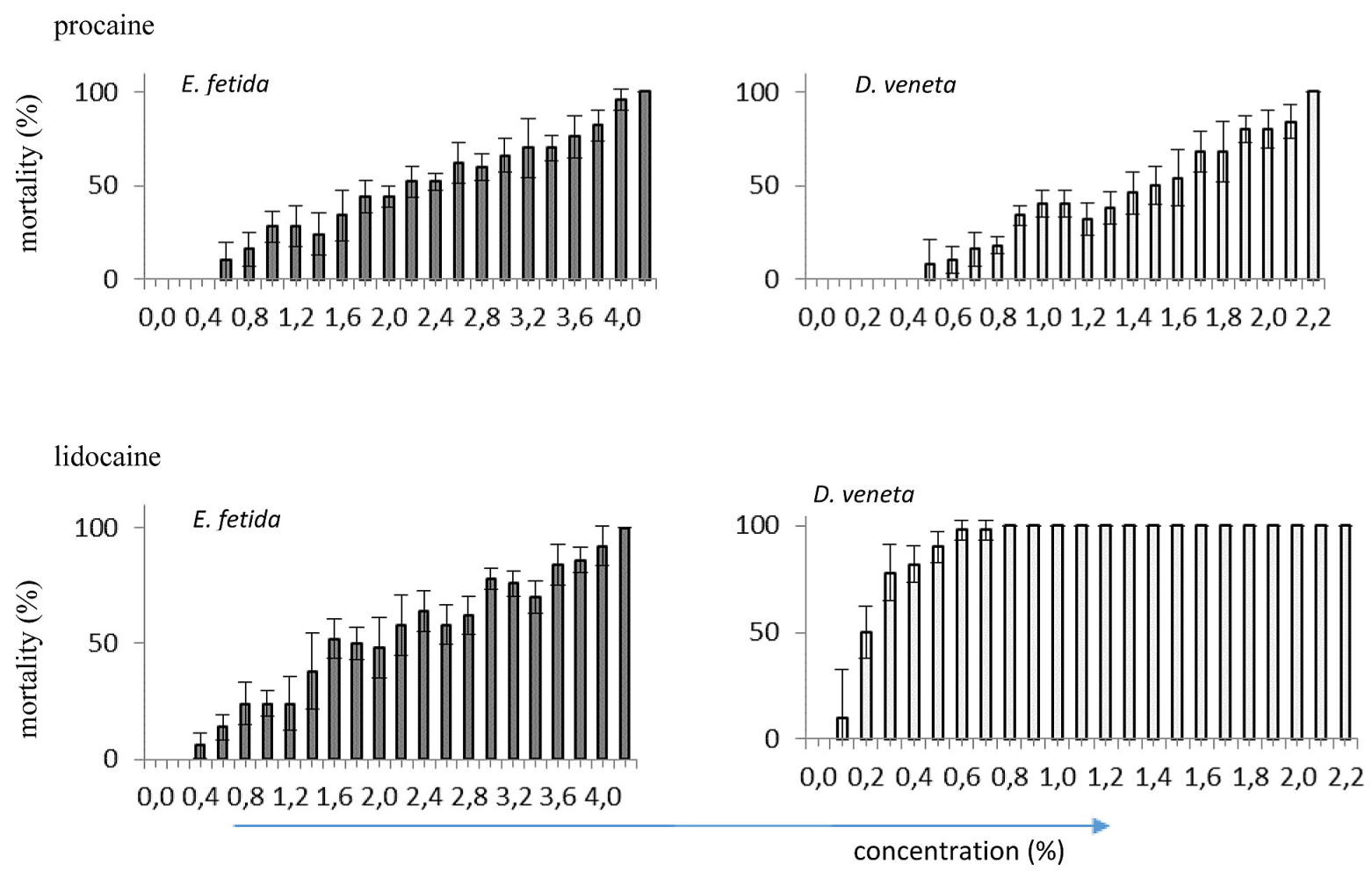

Figure 1. Earthworm mortality (\%) of E. fetida and D. veneta observed after $24 \mathrm{~h}$ of exposure to consecutive concentrations of procaine and lidocaine ( $24 \mathrm{~h}$ of exposure per substance $+24 \mathrm{~h}$ recovery) in paper-based contact tests $($ mean $\pm \mathrm{SD})$ 


\section{Effects to immobilize $E$. fetida and $D$. veneta earthworms using procaine and lidocaine}

Determining the effect of anesthesia on earthworms is a current issue that is used, for example, in the acquisition of coelomocytes or in other procedures related to penetrating the body of earthworms. Obtaining cells with a syringe after previous anesthesia of the animals guarantees that cells with adequate viability and purity of the suspension of isolated cells are obtained [Affar et al., 1998]. Previous studies showed that the use of prilocaine in earthworms $D$. veneta can be very useful [Podolak-Machowska et al., 2014]. Through the application of prilocaine, earthworms demonstrate an increased resistance to the stress associated with other experimental procedures, and do not respond to touch with the ejection of a coelomic fluid. Molnar et al. [2015] carried out anesthesia of $D$. veneta worms using prilocaine, conducting the research on nervous system regeneration, during which it was necessary to limit the loss of coelomic fluid by earthworms.

The current research has shown that the response of E. fetida earthworms to procaine and lidocaine observed after being placed in beakers containing different concentrations of solutions of test substances was similar. In the control groups $(0 \%)$ and at theconcentrations of $0.2 \%$, the earthworms showed average mobility and in this case the presence of ejected coelomic fluid was not observed. At higher concentrations of both substances used (0.4-4.2\%), rapid body movements of animals were visible, resulting in the discharge of a coelomic fluid (Table 2). At the first contact, lidocaine was found to be more toxic to $D$. veneta, because the subjects exposed to it reacted at a concentration of $0.2 \%$ whereas in the case of procaine, a concentration of $0.5 \%$ caused such reactions (Table 2). It has been shown that increases in concentration of procaine and lidocaine increased stress responses of the earthworms $E$. fetida and $D$. veneta (such as violent convulsion, discharge of coelomic fluid and morphological changes). Paracelsus previously commented that "dose creates poison", i.e. all substances are poisons, if they are present in appropriately high doses, and are completely harmless at low concentrations [Walker et al., 2002]. In the first phase of the experiment, earthworms, trying to avoid direct contact with the tested anesthetic, escaped from the tissue soaked in these substances, which indicates the functioning of their defense mechanisms, among which there is, for example, the avoidance of an irritant agent [Tyler et al., 1989]. This is related to the presence of chemoreceptors, sensitive to the chemicals located in the anterior and posterior segments of the body [Stephenson et al., 1997]. Similar behavior of earthworms was noticed by Malev et al. [2015] observing E. andrei in contact with contaminated soil and Podolak et al. [2011] in the case of Allolobophora chlorotica.

Table 1. $\mathrm{LC}_{05}, \mathrm{LC}_{50}$ and $\mathrm{LC}_{95}$ values for procaine and lidocaine determined in paper contact tests for earthworms E fetida (n=1100 os./subst.) and D. veneta (n=1150 os./subst.) (mean $\pm \mathrm{SD})$

\begin{tabular}{|c|c|c|c|c|}
\hline Species & \multicolumn{2}{|c|}{ Eisenia fetida } & \multicolumn{2}{c|}{ Dendrobaena veneta } \\
\hline Drugs & procaine & lidocaine & procaine & lidocaine \\
\hline 24 h LC0.5 & $0.32 \%$ a & $0.27 \%$ a & $0.41 \%$ a & $0.03 \%$ b \\
\hline $\mathbf{2 4}$ h LC50 & $\mathbf{2 . 3 0 \% ~ a ~}$ & $\mathbf{2 . 0 9 \%}$ a & $\mathbf{1 . 4 1 \% ~ a ~}$ & $\mathbf{0 . 2 5 \%} \mathbf{b}$ \\
\hline 24 h LC95 & $4.49 \%$ a & $4.32 \%$ a & $2.41 \%$ a & $0.59 \%$ b \\
\hline
\end{tabular}

Table 2. Reactions of $E$. fetida and $D$. veneta earthworms observed in contact with anesthetic solutions

\begin{tabular}{|c|c|c|c|c|c|c|c|}
\hline \multirow{2}{*}{\multicolumn{2}{|c|}{$\begin{array}{c}\text { Species } \\
\text { Drugs }\end{array}$}} & \multicolumn{3}{|c|}{ Eisenia fetida } & \multicolumn{3}{|c|}{ Dendrobaena veneta } \\
\hline & & \multirow{2}{*}{$\begin{array}{l}\text { procaine } \\
\geq 0.4 \%\end{array}$} & \multirow{2}{*}{\multicolumn{2}{|c|}{$\frac{\text { lidocaine }}{\geq 0.4 \%}$}} & procaine & \multirow{2}{*}{\multicolumn{2}{|c|}{$\begin{array}{c}\text { lidocaine } \\
\geq 0.2 \%\end{array}$}} \\
\hline \multirow{2}{*}{ Drug induced } & body movements & & & & $\geq 0.5 \%$ & & \\
\hline & fluid extrusion & $\geq 0.4 \%$ & \multicolumn{2}{|c|}{$\geq 0.4 \%$} & $\geq 0.5 \%$ & \multicolumn{2}{|c|}{$\geq 0.3 \%$} \\
\hline \multirow{2}{*}{$\begin{array}{c}\text { Drugs } \\
\text { effectiveness }\end{array}$} & $\begin{array}{l}\text { time to stop } \\
\text { spontaneous mobility } \\
\text { (min) }\end{array}$ & $150 \min (2 \% *)$ & $\begin{array}{l}40 \min \\
\left(1.4 \%^{*}\right)\end{array}$ & $\begin{array}{l}40 \min \\
\left(1.6 \%^{*}\right)\end{array}$ & $180 \min \left(1.8 \%^{*}\right)$ & $\begin{array}{l}35 \min \\
\left(1.3 \% \%^{*}\right)\end{array}$ & $\begin{array}{l}35 \min \\
\left(1.4 \%^{*}\right)\end{array}$ \\
\hline & $\begin{array}{c}\text { time of full } \\
\text { immobilization ( } \min )\end{array}$ & $150 \min (2 \% *)$ & $\begin{array}{l}95 \mathrm{~min} \\
\left(1.4 \%^{*}\right)\end{array}$ & $\begin{array}{l}90 \mathrm{~min} \\
\left(1.6 \%^{*}\right)\end{array}$ & $180 \min \left(1.8 \%^{*}\right)$ & $\begin{array}{l}40 \mathrm{~min} \\
\left(1.3 \%^{*}\right)\end{array}$ & $\begin{array}{l}40 \mathrm{~min} \\
\left(1.4 \%^{*}\right)\end{array}$ \\
\hline \multirow{2}{*}{$\begin{array}{l}\text { Application } \\
\text { safety }\end{array}$} & $\begin{array}{l}\text { live individuals after } \\
24 \mathrm{~h} \text { of recovery (\%) }\end{array}$ & $100 \%\left(2 \%{ }^{*}\right)$ & $\begin{array}{c}100 \% \\
\left(1.4 \%^{*}\right)\end{array}$ & $\begin{array}{c}100 \% \\
\left(1.4 \%^{*}\right)\end{array}$ & $0 \%\left(1.8 \%{ }^{*}\right)$ & $\begin{array}{c}100 \% \\
\left(1.3 \%{ }^{*}\right)\end{array}$ & $\begin{array}{c}100 \% \\
\left(1.4 \%{ }^{*}\right)\end{array}$ \\
\hline & $\begin{array}{l}\text { live individuals after } \\
48 \mathrm{~h} \text { of recovery (\%) }\end{array}$ & $40 \%(2 \% *)$ & $\begin{array}{c}100 \% \\
\left(1.4 \%{ }^{*}\right)\end{array}$ & $\begin{array}{c}100 \% \\
\left(1.4 \%^{*}\right)\end{array}$ & $0 \%\left(1.8 \%{ }^{*}\right)$ & $\begin{array}{c}100 \% \\
\left(1.3 \%^{*}\right)\end{array}$ & $\begin{array}{c}100 \% \\
\left(1.4 \%{ }^{*}\right)\end{array}$ \\
\hline
\end{tabular}


The results indicate that procaine is not suitable for immobilising E. fetida and D. veneta Despite the fact that the inhibition of spontaneous mobility and full immobilization of earthworms under the influence of procaine was found at concentrations of $2.0-4.2 \%$ (E. fetida) and $1.8-2.2 \%$ (D. veneta), this exposure also caused the mortality of the test animals after $48 \mathrm{~h}$ of recovery (Table 2). In comparison, lidocaine, was effective at immobilising earthworms. In the case of E. fetida, most of the used lidocaine concentrations were effective in immobilizing the test animals. The higher the concentration of the tested substance, the shorter the time needed to immobilize earthworms. Despite this, only $1.4 \%$ and $1.6 \%$ were found to be safe for earthworms, as all subjects survived both $24 \mathrm{~h}$ and $48 \mathrm{~h}$ contact (Table 2). The earthworms of the E. fetida species immobilised under the influence of lidocaine became stiff and assumed a characteristic shape. After 24 hours of recovery the animals lost stiffness and responded to touch, although in most cases they were not able to move quickly (Figure 2). While conducting the studies on the influence of lidocaine on E. fetida earthworms, the toxic effect of the substance was observed, and this depended on the concentration used. It was found that the lower the concentration of an anesthetic, the greater the intensity of morphological changes observed after $24 \mathrm{~h}$ of recovery. In lower concentrations, the animals stayed still longer than in the higher concentrations, so that the contact with the chemical was prolonged. In addition, it was noted that after this time, as the concentration increased, the amount of earthworms dropped compared to the control. After $48 \mathrm{~h}$ of "waking up", all individuals who survived looked similar to those in the control groups, showed a reaction to touch and moved. The individuals who did not survive $48 \mathrm{~h}$ had bloody ecchymosis on the surface of the body.

Lidocaine at the concentrations of $1.3 \%$ and $1.4 \%$ was effective in the reversible immobilisation of $D$. veneta earthworms. After using both concentrations, the animals survived for $48 \mathrm{~h}$ (Table 2). After this time, earthworms remained alive despite being unable to move quickly in reaction to touch.

As mentioned, the "anesthesia" of earthworms can also be important for the welfare of these laboratory animals during different experimental procedures. As shown by Walker et al. [2002], the sensitivity of individual earthworm species to the same substances may vary. The studies captured the differences in the effects of procaine and lidocaine on the E. fetida and $D$. veneta earthworm species. The collected data
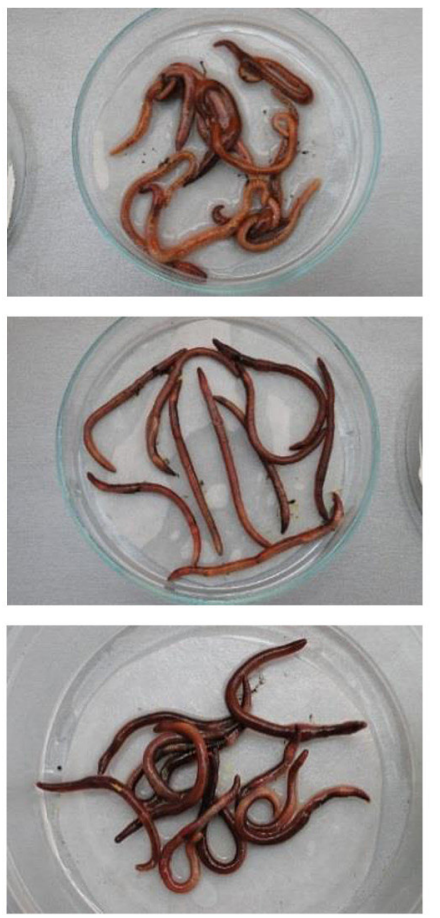
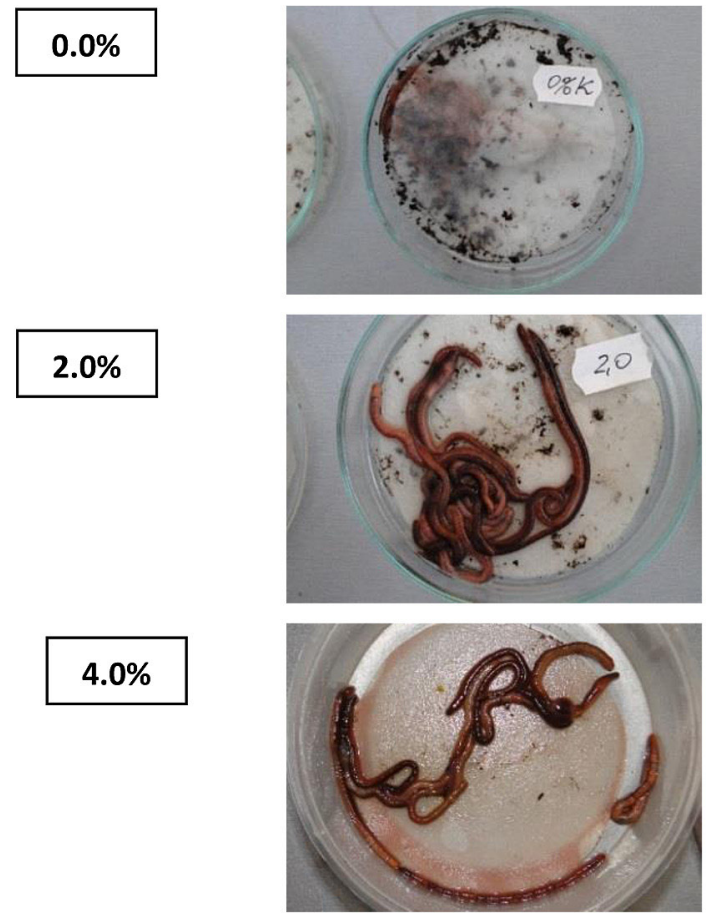

Figure 2. E. fetida earthworms after exposure to selected concentrations of lidocaine: a) immobilized (left side), b) after 24 hours of recovery (right side) 
supplemented information on the differences in sensitivity of the earthworms in contact with the chemical substances, and enabled the assessment of exemplary anesthetics for safe and effective anesthesia of these animals. This is of great importance and opens up a new perspective of research, because the actions aimed at improving the welfare of animals include, among others, satisfying their life needs, prevention and treatment of diseases and the use of laboratory techniques adapted to the capabilities of specific species. Since many research procedures may be considered cruel, the discovery of techniques of anesthesia, analgesics and euthanasia has been, and still is, essential for improving the welfare of laboratory animals. Their use is now a routine procedure accompanying many experiments [Baumans, 2005, Eysel et al., 2007]. The anesthesia of earthworms has been the subject of researchers' interest for various reasons. Studies in which earthworms were treated with anesthetic solution and its effectiveness observed while submerging the animal's end of the body in weak acid were carried out [Block et al., 1964]. However, as it turned out in later studies, this way of testing the effectiveness of anesthesia was not effective, since the acid gradually damaged tissues, raising doubts as to the results obtained [Suskevich et al., 1967].

Other methods of drug use were based on the anesthetization of earthworms with chloroform and ether [Kasprzak, 1986], $\mathrm{CO}_{2}$, urethane or heating or placing animals for a while on the "cold plate" to slow down their metabolism [Oguro et al., 1984, Cooper, 2011]. However, these methods caused the discharge of a coelomic fluid, which, for example in immunological studies, precludes further investigation [Bilej et al., 2011]. Prilocaine and lidocaine proved to be an effective and safe agent in the reversible immobilization of earthworms [Podolak-Machowska et al., 2013, 2014], and both substances are currently used in medicine. Lidocaine appears to be effective for longer durations and is a stronger anesthetic. It is also less toxic, and therefore is one of the best and most frequently used substances for local anesthesia [Danysz and Buczko, 2008]. Different reactions in various species of earthworms may have consequences for the assessment of the research results related to biomonitoring, but also in determining the toxicity of chemical substances [Langdon et al., 2005].

\section{CONCLUSIONS}

The reactions of earthworms in contact with anesthetics were different:

a) The mortality of earthworms increased along with the concentrations of procaine and lidocaine. The $\mathrm{LC}_{05}, \mathrm{LC}_{50}, \mathrm{LC}_{95}$ values were significantly different in the analyzed anesthetics and species of earthworms tested (for E. fetida - procaine: $\mathrm{LC}_{05}=0.32 \pm 0.12 \%$, $\mathrm{LC}_{50}=2.30 \pm 0.17 \%, \mathrm{LC}_{95}=4.49 \pm 0.37 \%$, lidocaine: $\mathrm{LC}_{05}=0.27 \pm 0.18 \% ; \mathrm{LC}_{50}=2.09 \pm 0.24 \%$; $\mathrm{LC}_{95}=4.32 \pm 0.25 \%$ ) (for D. veneta - procaine: $\mathrm{LC}_{05}=0.41 \pm 0.12 \% ; \mathrm{LC}_{50}=1.4 \pm 0.1 \%$; $\mathrm{LC}_{95}=2.4 \pm 0.3 \%$; lidocaine: $\mathrm{LC}_{05}=0.03 \pm 0.05 \%$; $\mathrm{LC}_{50}=0.25 \pm 0.05 \% ; \mathrm{LC}_{95}=0.59 \pm 0.04 \%$ ).

b) The possibility of using a higher concentration range of procaine and lidocaine for E. fetida than for D. veneta, as E. fetida demonstrated a greater resistance to the stress caused by the action of chemical substances. The response to this stress varied and depended on the concentration used; however, higher concentrations of anesthetics caused rapid body movements and the discharge of the coelomic fluid as well as morphological changes observed after 48 hours.

c) Procaine was not effective in immobilizing earthworms, but lidocaine proved effective in reversibly immobilizing both species. For $E$. fetida, lidocaine in the concentrations of 1.4 and 1.6 at 95 and $90 \mathrm{~min}$, respectively, resulted in full immobilization of animals, which then survived following $24 \mathrm{~h}$ and $48 \mathrm{~h}$ of recovery. For $D$. veneta, lidocaine in the concentrations 1.3 and 1.4 during $40 \mathrm{~min}$ proved effective and safe to use, as all individuals survived following $24 \mathrm{~h}$ and $48 \mathrm{~h}$ of recovery.

\section{Acknowledgements}

We would like to thank dr hab. Tadeusz Librowski, prof UJ (Jagiellonian University, Medical College, Poland) for providing substances for testing and Dr. Frank Ashwood (Forest Research, UK) for help in language correction.

\section{REFERENCES}

1. Affar E. B., Dufour M., Poirier G. G., Nadeau D. 1998. Isolation, purification and partial characterization of chloragocytes from the earthworm species Lumbricus terrestris. Molecular and Cellular Biochemistry, 185, 123-133. 
2. Baumans V. 2005. Science-based assessment of animal welfare: laboratory animals. Scientific and Technical Review of the Office International des Epizooties (Paris), 2, 503-514.

3. Bilej M., Prochazkova P., Silverova M., Jaskova R. 2011. Earthworm immunity. Advances in Experimental Medicine and Biology, 708, 66-79.

4. Block B. P., Potts D. J., Finney R. S. H. 1964. A simple method for the evaluation of local anaesthetic activity using earthworms. Journal of Pharmacy and Pharmacology, 16, 85-88.

5. Bouazizi H., Narchi P., Mercier F. J., Khoury A., Poirier T., Benhamou D. 1998. The use of a selective axillary nerve block for outpatient hand surgery. Anesthesia and Analgezia, 86, 746-748.

6. Bujak-Giżycka B., Grębska A., Jakubowski A., Jawień J., Lorkowski B., Marcinkiewicz E., Olszanecki R., Wołkow P., Woroń J. 2009. Farmakologia po prostu. Podręcznik dla studentów kierunków medycznych. [Ed.] Korbut R. Wydawnictwo Uniwersytetu Jagiellońskiego (WUJ) Kraków.

7. Butterworth J. F., Moran J. R., Whitesides G. M., Strichartz G. R. 1987. Limited nerve impuls blockade by 'leashed' local anesthetics. Journal of Medicinal Chemistry, 30, 1295-1302.

8. Cooper J. E. 2011. Anesthesia, analgesia and euthanasia of invertebrates. ILAR Journal, 52, 196-204.

9. Danysz A., Buczko W. 2008. Kompendium farmakologii i farmakoterapii - Podręcznik dla studentów medycyny. Elsevier Urban and Partner. Wrocław. Wyd. V, 139-144.

10. Eysel U., Haverich A., Heldmaier G., Hoffmann B., Lower W., Treue S., Wagner H., Wolf E., Wollnik F., Exner C., Bode H. J., Blumer K., Giese C. 2007. Animal experiments in research (Deutsche Forschungsgemeinschaft). [Ed.] Senate Commission on Animal Protection and Experimentation. Deutsche Forschungsgemeinschaft - Bonn: Lemmens Medien GmbH, 1-44.

11. Feinstein M. B., Volpi M., Perrie S., Makriyannis A., Sha'afi R. I. 1977. Mechanisms of local anesthetic action on the permeability of erythrocytes, leukocytes and liposomes containing the erythrocyte anion channel protein. Molecular Pharmacology, 13, 840-851.

12. Kasprzak K. 1986. Skąposzczety glebowe III, dżdżownice (Lumbricidae). PAN Instytut Zoologii. Klucz do oznaczania bezkręgowców Polski, Wydawnictwo Naukowe PWN. Warszawa.

13. Langdon C. J., Hodson M. E., Arnold R. E., Black $\mathrm{S}$. 2005. Survival, $\mathrm{Pb}$-uptake and behavior of three species of earthworm in $\mathrm{Pb}$ treated soils determined using an OECD-style toxicity test and a soil avoidance test. Environmental Pollution, 138, 368-375.

14. Langwiński R. 2008. Środki miejscowo znieczulające. [In:] Farmakologia - Podstawy farmakoterapii -
Podręcznik dla studentów medycyny i lekarzy. [Ed.] Kostowski W., Herman Z. S. Tom 1. Wydawnictwo Lekarskie PZWL. Warszawa, 450-457.

15. Łebkowska M., Załęska-Radziwiłł M., Słomczyńska B. 2004. Toksykologia środowiska, ćwiczenia laboratoryjne. [Ed.] Łebkowska M. Oficyna Wydawnicza Politechniki Warszawskiej, Warszawa.

16. Malev O., Contin M., Licen S., Barbieri P., De Nobili M. 2015. Bioaccumulation of polycyclic aromatic hydrocarbons and survival of earthworms (Eisenia andrei) exposed to biochar amended soils. Environmental Science and Pollution Research, DOI 10.1007/s11356-015-5568-2.

17. Molnar L., Pollak E., Skopek Z., Gutt E., Kruk J., Morgan A. J. 2015. Immune system participates in brain regeneration and restoration of reproduction in earthworm Dendrobaena veneta. Developmental and Comparative Immunology, 52, 289-279.

18. Mepham B. 2008. Bioetyka - Wprowadzenie dla studentów nauk biologicznych. Wydawnictwo Naukowe PWN, Warszawa.

19. OECD Guideline for testing of chemicals. 1984. Earthworm, Acute Toxicity Tests. OECD. Paris, France, 207, 1-9.

20. Oguro C., Sasayama Y., Nonaka K. 1984. Effects of anesthesia on the electrolyte concentrations In blond and coelomic fluid of the earthworm, Pheretima communissima. Comparative Biochemistry and Physiology, 79C: 277-279.

21. Podolak-Machowska A., Kostecka J., Librowski T., Płytycz B. 2012. New uncontroversial model for testing anesthetic drugs - measurement of spontaneous and induced earthworm mobility. (Ed.) H. Lach, Kraków, 14-15 czerwiec, 2012: 296-297. The XXI International Symposium of the Polish Network of Molecular and Cellular Biology. "Molecular and physiological aspects of regulatory processes of the organism", 14-15. 06. 2012, Kraków.

22. Podolak-Machowska A., Kostecka J., Librowski T., Płytycz B. 2013. The use of selected anaesthetic drugs in search of a method for improving earthworms' welfare. Journal of Ecological Engineering, 14, 83-88.

23. Podolak-Machowska A., Kostecka J., Librowski T., Santocki M., Bigaj J., Płytycz B. 2014. Effects of anesthetic compounds on responses of earthworms to electrostimulation. Folia Biologica (Kraków), 62, 155-162.

24. Podolak A., Piotrowska E., Klimek M., Klimek B. A., Kruk J., Płytycz B. 2011. Effects of nickel, zinc, and lead-contaminated soil on burrowing rate and coelomocytes of the earthworm, Allolobophora chlorotica. Folia Biologica (Krakow), 59, 91-97.

25. Sadowski B. 2012. Biologiczne mechanizmy zachowania się ludzi i zwierząt. Wydawnictwo Naukowe PWN, Warszawa. 
26. Stephenson G. L., Kaushik A., Kaushik N. K., Solomon K. R., Steele T., Scroggins R. P. 1997. Use of an avoidance-response test to assess the toxicity of contaminated soils to earthworms. [In:] Advances in Earthworm Ecotoxicology [Ed.] Steppard S. C., Bembridge J. D., Holmstrup M. L. SETAC Technical Publications Series, 67-81.

27. Suskevich J., Campbell A. H., Lord G. H. 1967. A modification of a method for the evaluation of topical anaesthesia in the earthworm. Journal of Pharmacy and Pharmacology, 19, 456-459.

28. Tyler G., Balsberg Pahlsson A. M., Bengtsson G., Baath E., Tranvik L. 1989. Heavy-metal ecology of terrestrial plants, microorganisms and inverte- brates. Water, Air, and Soil Pollution, 47, 189-215.

29. Walker C. H., Hopkin S. P., Sibly R M., Peakall D. B. 2002. Podstawy ekotoksykologii. [Ed.] Migula P. Wydawnictwo Naukowe PWN, Warszawa.

30. Wang Y., Cang T., Zhao X., Yu R., Chen L., Wu C., Wang Q. 2012. Comparative acute toxicity of twenty-four insecticides to earthworm, Eisenia fetida. Ecotoxicology and Environmental Safety, $79,122-128$.

31. Zuharah W. F., Fadzly N., Ali Y., Zakaria R., Juperi S., Asyraf M., Dieng H. 2014. Larvicidal efficacy screening of Anacardaciae crude extracts on the dengue hemorrhagic vector, Aedes aegypti. Tropical Biomedicine, 31, 297-304. 